\title{
Ön Sözleri Tanıklığında Bir Çevirmenin Serüveni: Çeviri Tarihimizde Nurettin Sevin
}

\author{
The Adventure of a Translator in the Witness of the Prefaces: Nurettin Sevin in \\ Turkish Translation History
}

\author{
Araştırma/Research
}

\section{Burcu KANIDINÇ}

Arş. Gör., Adana Alparslan Türkeş Bilim ve Teknoloji Üniversitesi, İnsan ve Toplum Bilimleri Fakültesi, Mütercim Tercümanlık Bölümü, bkanidinc@atu.edu.tr, ORCID ID: orcid.org/0000-0001-5681-9101

\section{ÖZET}

Bu çalışmada, çevirmen Nurettin (Nureddin) Sevin'in çevirilerine yazdığı ön sözler tanıklığında çeviri politikasına dair izlenimlerde bulunmak amaçlanmaktadır. Çalışmanın inceleme nesneleri, Cumhuriyet döneminin planlı çeviri hareketini başlatan Tercüme Bürosunun çevirmenlerinden Nurettin Sevin'in çevirilerine yazdığı ön sözlerdir. Bunun sebebi, çeviribilim alanında daha önce Nurettin Sevin'in çevirilerine yazdığı ön sözler üzerine ayrı bir çalışmanın yapılmamış olması ve Sevin'in çeviri eserlerine yazdığı ön söz metinlerinin çeviribilim bağlamında değerli bilgiler içermesidir. İnceleme sırasında "eser/yazar/dil seçimini etkileyen faktörler", benimsenen çeviri stratejileri ve çevirilerde çevirmenin rolü üzerinde durulmuştur. Dönemin, çevirmenin politikasına ve çeviriye ilişkin bilgileri ihtiva ettiği için ön sözlerin dışında son sözler, notlar, yayınevlerine ait çeviri ve telif eserlerin listeleri, yayınevlerinin yayımlamış olduğu ve yayımlayacağı eserlerin reklamını yapan kısa tanıtım yazıları da çalışmanın kapsamında yer almaktadır. Çalışmanın kavramsal çerçevesi olarak Gideon Toury'nin "süreç öncesi çeviri normları” esas alınmıştır. Toury'nin "erek odaklı" betimleyici bir yaklaşımla temellendirdiği ismi geçen normlar, iki başlık altında incelenmektedir: "çeviri politikası" ve "çevirinin doğrudanlığı". Çalışmada, ön sözlerin ışığında, adı geçen çevirmenin eser/yazar seçimini etkileyen faktörler ve çeviri yapmak üzere tercih edilen çevirinin kaynak dilden doğrudan çeviri mi yoksa ara dil çevirisi mi olduğu konusu, "süreç öncesi çeviri normları" kapsamında incelenmiştir. Söz konusu ön sözlerin yanında son sözlerin, notların, yayınevlerine ait çeviri ve telif eserlerin listelerinin, yayınevlerinin yayımlamış olduğu ve yayımlayacağı eserlerin reklamını yapan kısa tanıtım yazılarının da dönemlerinin ve çevirmeninin çeviri ve kültür manzarasına kısmi olarak da olsa ışık tutabileceği öngörülmektedir. 
Anahtar Sözcükler: Nurettin (Nureddin) Sevin, Hilmi Kitabevi, Tercüme Bürosu, ön söz, süreç öncesi çeviri normları

\section{ABSTRACT}

This study aims to examine the translation policy of translator Nurettin (Nureddin) Sevin in the light of translator prefaces within the framework of Translation Studies. Prefaces written by Nurettin Sevin, one of the translators of Translation Bureau that initiated the planned translation movement of the Republican era, are the research objects of the study. This is due to the fact that there has not been any separate study on the prefaces of Nurettin Sevin in the field of Translation Studies and translator prefaces written by Sevin contain valuable information in the context of Translation Studies. Throughout the study, factors affecting selection of literary works/authors, translation strategies adopted and the role of translator in aforementioned translations are emphasized. Epilogues, as they provide an insight about the period, translator's and translation's policy, notes, lists of translation and other works belonging to the publishers, the short promotional articles published and advertised by the publishers are also included in the scope of the study. The conceptual framework of the study is "preliminary translation norms" of Gideon Toury. These norms that Toury bases as a "target oriented" descriptive study, are examined under two headings: "translation policy" and "directness of translation". In the study, starting from the prefaces, factors affecting above-mentioned translator's selection of literary works/ authors and whether the preferred language for translation is the ultimate source language or translation of any mediating language have been examined. It is foreseen that aforementioned prefaces, epilogues, notes, lists of translation and other works belonging to the publishers, the short promotional articles published and advertised by the publishers may shed some light on the landscape of translation and culture.

Keywords: Nurettin (Nureddin) Sevin, Hilmi Kitabevi, Translation Bureau, preface, preliminary norms

\section{Giriş}

Türkiye Cumhuriyeti'nin kuruluşundan sonra yapılan reformların en önemlilerinden biri 1928 yılında gerçekleştirilen Harf Devrimi'dir. Bu devrimin ardından Türk edebiyat ve kültür dizgesine özellikle Batı'dan çeviri yoluyla eserler kazandırma çalışmaları başlatılmıştır. Özel yayınevi sahiplerinin bireysel çabalarının yanında özellikle 1940 yılında Maarif Vekili Hasan Ali Yücel tarafından Tercüme Bürosunun kuruluşuyla bu çaba en üst düzeyde gösterilmiştir. Devlet eliyle desteklenen bu planlı çeviri hareketinde, çevirisi yapılacak olan eserlerin tek bir çatı altında toplanıp Tercüme Bürosu denetim mekanizması altında çevirmenlere iletilmesi, Tercüme Bürosu çevirmenlerinin de sistematik ve planlı bir şekilde çalışmasına olanak sağlamıştır (Krş. Tahir-Gürçağlar, 2008, ss. 39-41). Çevirmenler ise gerek Tercüme Bürosundan önce özel yayınevleriyle çalışırken gerek Tercüme Bürosu çatısı altında, çeviri eserlerine "çeviri metinden önce gelen veya onu izleyen, metnin konusunda üretilen bir söylemden oluşan" (Genette, 1997 , s. 161), kendi yazdıkları ön sözlerle "çeviri politikaları"na ışık tutacak bilgiler

\footnotetext{
${ }^{1}$ Aksi belirtilmedikçe tüm çeviriler tarafıma aittir.
} 
vermişlerdir. Metni sunmak için çepeçevre saran ve genişleten üretimler olarak da tanımlanabilen bu "yan metinler" (Genette, 1997, s. 14), metni çevreleyen metnin ön sözlerinin yanı sıra notları, dış kapağı, başlık sayfası, tanıtıcı yazıları gibi basılmış özellikleri ve metnin dışında metinden bağımsız dolaşıma giren görüşme, mektup, pazarlama materyalleri olarak sınıflandırılabilmektedir (Krş. Genette, 1997, ss. 1-15). "Belirli bir zaman diliminde, belli bir toplumun tüm söylem evreni ile birlikte çalışan" (Kovala, 1996, s. 135) yan metinler, "kültürel üretim süreçlerini anlaşılır ve okuyucuya görünür kılan" (Waring, 1995, s. 455) izler bırakmaktadır. Peter Newmark, "çevirmenlerin, insanları ve ulusların birbirlerini daha iyi anlamalarını sağlama konusunda başlıca rolü üstlenecek kişiler olarak görülmesi gerektiği"ni vurgularken, onların yazdıkları ön sözlerin de "çeviri eserler kadar araştırmacının dikkatini çekmesi gerektiğini” savunmaktadır (akt. Karadağ, 2012, s. 50). Çevirmen ön sözlerini, çeviri araştırmaları için besleyici bir kaynak olarak yorumlayan Dimitriu'nun (2009) yanı sıra, benzer şekilde ön söz/son söz odaklı çeşitli çeviribilim çalışmaları (Akbulut, 2011; Karadağ \& Bozkurt, 2014; Tahir-Gürçağlar, 2002)² bulunmaktadır. Bu doğrultuda çalışmanın konusu, çeviri tarihimize tanıklık edeceği düşünülen Nurettin Sevin'in çevirilerine yazdığı ön sözlerdir.

Çalışmanın amacı, Cumhuriyet döneminin planlı çeviri hareketini başlatan Tercüme Bürosunun çevirmenlerinden Nurettin Sevin'in (Bk. Ek.1) hem Hilmi Kitabevi'yle hem de Tercüme Bürosuyla çalışırken çevirilerine yazdığı ön sözler tanıklığında, çevirmenin "çeviri politikası"na dair çıkarımlarda bulunmaktır. İlgili alanyazında, çalışmalarının bir bölümünde çevirmen Nurettin Sevin'in çevirilerine yer veren çalışmalar ${ }^{3}$ bulunsa da Nurettin Sevin'in çevirdiği eserlere yazdığı ön sözlerini çeviribilim bağlamında ele alan ayrı bir çalışmanın bulunmadığı görülmektedir. Çalışmanın temel sorunsalı, Nurettin Sevin'in çevirmen kimliği ile çevirilerine yazdığı ön sözleri üzerine ayrı bir çalışmanın yapılmamış olması ve çeviri eserlerine yazdığı ön söz metinlerinin çeviribilim bağlamında önemli bilgiler içermesidir. Çalışmada, yazdığı ön sözler tanıklığında, çevirmen Sevin'in eser/yazar seçimini belirleyen faktörler ve tercih edilen çevirinin kaynak dilden doğrudan bir çeviri mi yoksa ara dil çevirisi mi olduğu konusu, 'süreç öncesi çeviri normları' bağlamında incelenip söz konusu döneme ait çeviri politikası tespit edilmeye çalışılmıştır.

Çalışmanın amacına ulaşmak için öncelikle Nurettin Sevin'in yazar ve çevirmen kimliği kısaca irdelenecek, ardından dönemin çeviri manzarasına ışık tutabileceği düşünüldüğünden Sevin'in Tercüme Bürosu çevirmeni olmadan önce çevirilerinin yayımlandığı Hilmi Kitabevine ve sonrasında Tercüme Bürosuna dair bilgiler çeviribilim bağlamında ele alınacaktır. Çalışmanın yöntemsel yaklaşımı gereği, Sevin'in kendi çevirilerine yazdığı ön sözler, Gideon Toury'nin "süreç öncesi çeviri normları", "çeviri

\footnotetext{
${ }^{2}$ Ayrıntılı bilgi için bkz. Karadağ, Bozkurt \& Alimen, 2015.

${ }^{3}$ Bu çalışmalardan bazıları için bkz. Aksoy, 2016; Kanıdinç, 2018; Kuleli, 2016; Sancaktaroğlu Bozkurt, 2014.
} 
politikası" ve "çevirinin doğrudanlığı" kavramsal çerçevesi içinde incelenip çeviribilim bağlamında bir sonuca varılmaya çalışılacaktır.

\subsection{Yazar ve Çevirmen Kimliğiyle Nurettin Sevin}

1900 yılında İstanbul'da doğan Nurettin Sevin'in William Shakespeare'den çevirdiği, Maarif Matbaası tarafından yayımlanan Venedik Taciri (1943) ve Bernard Shaw'dan çevirdiği Milli Eğitim Basımevi tarafından yayımlanan Caesar'la Kleopatra'nın (1945) ilk sayfasında yazıldığı üzere, çevirmen Nurettin Sevin Ankara Üniversitesi Siyasal Bilgiler Okulu İngilizce okutmanıdır (Bk. Ek-6a). Sevin, Narlı Ev'e (1939) yazdığı ön sözde, bu tarihte Londra'da bulunduğunu özellikle belirtmiştir. Kendisinin daha önce de İngiltere'deki “Bath School of Drama”yı bitirdiği bilinmektedir (Aşır, 2019).

Sevin, çevirmen kimliğiyle Salomé (Wilde, 1935), Yaz Ortasında Bir Gecelik Bir Rüya (Shakespeare, 1936), Bahtiyar Prens ve Başka Masallar (Wilde, 1938), Narlı Ev (Wilde, 1939), Venedik Taciri (Shakespeare, 1943), Bir Yaz Dönümü Gecesi Rüyası (Shakespeare, 1944), Caesar'la Kleopatra (Shaw, 1945), Tiyatro Sanatı Hakkında (Craig, 1946), Hırçın Kız (Shakespeare, 1946), Ehemmiyetsiz Bir Kadın (Wilde, 1948), Julius Caesar (Sezar) (Shakespeare, 1942/1958) adlı eserlerin çevirisini yapmıştır. Julius Caesar çevirisi, Güzel Sanatlar Umum Müdürlüğü’nün açtığı tercüme müsabakasında Tercüme Bürosunca birinci seçilmiştir. Çeviri eserlerinden Salomé, Yaz Dönümü Gecesi Rüyası, Bahtiyar Prens ve Başka Masallar, Narlı Ev çevirileri Hilmi Kitabevi'nden yayımlanmıştır. Sevin'in 1936 yılında Yaz Ortasında Bir Gecelik Bir Rüya adıyla Hilmi Kitabevi'nden yayımlanan çevirisi, 1944 yıında Bir Yaz Dönümü Gecesi Rüyası başlığıyla, Tercüme Bürosu gözetimindeki Maarif Matbaası tarafından tekrar ele alınıp düzenlenmiş ve yeniden yayımlanmıştır (Sancaktaroğlu Bozkurt, 2014, s. 98). Çevirinin 1936'da Hilmi Kitabevinden çıkan örneğinde, Yaz Dönümü Gecesi Rüyası'nda, yayınevi sahibi İbrahim Hilmi Çığıraçan'ın bir ön sözü bulunurken 1944 yılında Maarif Matbaasının bastığı Bir Yaz Dönümü Gecesi Rüyası'nda herhangi bir ön söz bulunmamaktadır. Venedik Taciri, Caesar'la Kleopatra, Tiyatro Sanatı Hakkında, Hırçın Kız, Ehemmiyetsiz Bir Kadın ve Julius Caesar (Sezar), Nurettin Sevin'in Maarif Matbaası/Milli Eğitim Basımevi adı altında Tercüme Bürosu kontrol ve gözetiminde yayımlanan diğer çeviri eserleridir.

1946 yılında Milli Eğitim Basımevi tarafından yayımlanan, Gordon Craig'ten dilimize çevirdiği Tiyatro Sanatı Hakkında adlı çeviri eserin ilk sayfasında kendisinden "Devlet Konservatuarı Öğretmenlerinden Nureddin SEVIN" şeklinde bahsedilmiştir. Ayla Algan ve Haşmet Zeybek ile yapılan bir röportajda belirtildiği üzere, kendisi aynı zamanda Devlet Konservatuvarında tiyatro öğrencilerine diksiyon öğretmenliği yapmaktadır ${ }^{4}$. Ayla Algan kendisinden, "Nurettin Sevin, bizim diksiyon hocamızdı, nasıl çalışılması gerektiğini, sahnede nasıl nefes alınacağını, oyunun üzerine nasıl gidilmesi gerektiğini

4 “Nurettin Bey evini taşıdı, karısıyla İstanbul’a geldi, LCC'de diksiyon dersi vermeye başladı" (Saral, 1999, 1 Nisan, para 2). 
gösteriyordu. Ben sevgili Nurettin Sevin'den çok şey öğrendim" şeklinde söz etmektedir (Er, 2009, Tanıtım Bülteni). Sevin, tiyatroya olan ilgisine istinaden de İngiltere'de tiyatro eğitimi almış, ardından Devlet Konservatuarında Tiyatro Bölüm şefliği yapmıştır. Yazar kimliğiyle kaleme aldığı Mir'at-ı Şikeste (1920)5 , Türk Gölge Oyunu (1968), On Üç Asırlık Türk Kıyâfet Târihine Bir Bakış (1973) adlı eserlerinin yanı sıra tiyatro, diksiyon ve fonetik üzerine yazdığı çeşitli inceleme yazıları da bulunmaktadır. 1947 yılında yayımlanan Milletlerarası Fonetik Işsaretleriyle Konuşma Dilimiz adlı eserini de Turgut Erem ile birlikte kaleme dökmüş, Türk fonetik transkripsiyonuna bir inceleme yazısı ile katkıda bulunmuştur. Nurettin Aram ile birlikte çocuklar için hazırladığı Müslüman Çocuğun Kitabı (1948) Milli Eğitim Basımevi tarafından basılmıştır. Alexius'un Sancıları (1968) isimli oyunu ise Türk Ev Kadınları Derneği tarafından ikincilik ödülüne layık görülmüştür. Yazarlığı ve çevirmenliğinin yanı sıra başarılı bir eğitmen de olan Sevin, 1973 yılında Kültür Bakanlığı'nın düzenlediği Karagöz metinleri yazımı ve gösterisi hakkında eğitim veren kursun hocalarından biri olarak atanmış, kursun ardından Dışişleri bakanlığımızca Tunus'a gönderilen beş kişilik Karagöz ekibinin içinde kendine yer bulmuştur ("Karagöz kursu ve Tunus'a giden Karagöz ekibi", 2018). TRT Dış Yayınlar Dairesi'ne özel "Türk kültür ve sanatı üzerine konuşmalar" hazırladığı ve 1975 'te vefat ettiği bilinmektedir (Aşır, 2019).

\subsection{Hilmi Kitabevi}

Nurettin Sevin'in Tercüme Bürosu kurulana kadar çevirdiği Salomé (1935), Yaz Ortasında Bir Gecelik Bir Rüya (1936), Bahtiyar Prens ve Başka Masallar (1938) ve Narlı Ev (1939), Tüccarzâde İbrahim Hilmi (Çığıraçan)'ın kurduğu Hilmi Kitabevinde basılmıştır. Kurucu İbrahim Hilmi, önceleri Kitabhane-i İslam, Kitabhane-i İslam ve Askeri, Hilmi Kitaphanesi ve son olarak Hilmi Kitabevi adını verdiği yayınevinde çok sayıda eserin baskısını yaparak Türk telif ve çeviri edebiyat dizgesine büyük katkılar sunmuştur (Ocak, 2003; Üstün Külünk, 2018). İbrahim Hilmi Çığıraçan, 1913’te yazdığı “Avrupalılaşmak” adlı eserinde modernleşmenin gerekliliği ve bu konuda Batı'nın örnek alınması gerektiği konularında görüş bildirmiş, eğitim ve öğretimdeki iyileştirmelerle ancak devletin ve milletin refaha kavuşabileceğini ifade etmiştir. Kurduğu yayınevinde kendi yazdığı ders kitaplarını yayımlamıştır. Ders kitaplarının yanında edebi, siyasi, sosyal ve dini eserler de basmıştır. Erken Cumhuriyet döneminde yayımlattığı Kur'an tercümelerinin bazı kısımlarını çocuklara uyarlayarak onların anlayabileceği hale getirmiştir (Erşahin, 2004, s. 18). 1946 yılında yayıncılığında 50. Yılını tamamlayınca Türk Editörler Derneği tarafından görkemli bir kutlama yapılmıştır, yayıncılığa yaptığı katkılar dile getirilmiştir (Erşahin, 2004, s. 19).

II. Meşrutiyet'in ilanının ardından alevlenen dilde sadeleşme tartışmaları etrafında yazdığı Tasfiye-i Lisana Muhtaç Mıyız? (1911) adlı eserinde Çığıraçan, Avrupa dillerine kıyasla Türkçeyi öğrenmenin ne denli zor olduğunu ve uzun seneler aldığını belirtmiştir. Çığıraçan'a göre bunun sebebi, lisanımızın "karmakarışık bir çorba”ya dönmesidir (Ocak, 2008, s. 96). Zira lisanımızı korumak için Türkçede sadeleştirilmeye

${ }^{5}$ Nurettin Semin adıyla yazmıştır. 
gitmek bir mecburiyettir (Ocak, 2008, s. 97). Çığıraçan bu eseri yazarak Türkçenin içinde bulunduğu çetrefil durumu ileri sürmüş ve çözüm arayışı için adeta bir çağrıda bulunmuştur. Dil konusundaki hassasiyetini Hilmi Kitabevinde bastığı telif eserlerde de göstermiştir. Kendisi telif eserlerin basımına verdiği önemin yanı sıra çeviri eserlerin seçimi konusundaki hassasiyetini Hilmi Kitabevinden çıkan çeviri eserlere yazdığı ön sözlerde belirtme ihtiyacı duymuş ve bunu "Yaz artasında bir gecelik rüya ismile ingilizceden türkçeye manzum olarak çevrilen bu eser şüphesiz Nureddin Sevin için büyük bir muvaffakiyettir" (Shakespeare (çev. Sevin), 1936, s. 14) sözleriyle dile getirmiştir. "Hiç şüphesiz Nureddin Sevin de bu eserle şiir ve edebiyatımızda güzel bir mevki ihraz edeceklerdir" diyerek çeviri için seçilen eserin ve çevirmen Sevin'in yaptığı çeviriyle elde edeceği konumun önemine de ayrıca işaret etmiştir (Shakespeare (çev. Sevin), 1936, s. 14). Çeviri eserin yazarına övgülerde bulunarak Hilmi Kitabevinin kaynak metin seçim politikasına dair "eserlerindeki edebi kıymet ve inceliği, tasvirlerindeki kuvvet ve derinliği, şiirlerindeki güzellik ve ahengi itibarile yalnız kendi devrinin değil, bütün devirlerin şairi sayılabilir" ifadesini kullanmıştır (Shakespeare (çev. Sevin), 1936, s. 7).

Yeni Türk edebiyat dizgesinin oluşumuna yön veren özel yayınevi sahiplerinin önde gelenlerinden biri olarak Çı̆̆ıraçan, İstanbul'daki yayıncıları temsilen katıldığı Birinci Türk Neşriyat Kongresi'nde (BTNK) özellikle "tercümelerin serbestçe tatbiki" üzerinde görüş bildirmiş ve ancak çeviri yoluyla Batı külliyatındaki yararlı eserlerin ${ }^{6}$ dilimize kazandırılması sonrasında "bizde yazılacak ve rağbet görecek milli bir eserin yabancı dillerde çıkması" intimalinden bahsetmiştir (BTKN, 1939, s. 377). Hatta "iyi bir tercüme yapana" ödül vermenin teşvik edilmesi gerektiğini, "tercüme eserlere muhtacız" savı ile desteklemiştir (BTKN, 1939, s. 378). Çığıraçan'ın yayıncılık faaliyetlerine ilişkin sunduğu raporda özellikle çeviri eserler ve bunların seçimi hakkındaki görüşlerini vurgulaması yayıncılığı ile döneminin önde gelen isimlerinden biri olarak çeviri eserlere gösterdiği değerin bir göstergesidir. Nitekim, Birinci Türk Neşriyat Kongresi'nde hem Çığıraçan'ın hem de kongreye katılan tüm katılımcıların görüşlerinin değerlendirilmesi sonrasında, dönemin çeviri hareketlerine sistemli ve düzenli bir nitelik kazandırma yolunda atılan bir adım olarak Tercüme Bürosunun kurulması kararlaştırılmıştır.

\subsection{Tercüme Bürosu}

1939 yılında toplanan Birinci Türk Neşriyat Kongresinde alınan karara istinaden 1940 yılında devlet destekli bir çeviri planlamasına gidilmiş ve bu planı uygulamak için "devlet destekli bir çeviri kurumunun oluşturulmasına giden süreçte bir dönüm noktası" olan Tercüme Bürosunun kurulması uygun görülmüştür (Tahir-Gürçağlar, 2018, s. 70). Milli Eğitim Bakanlığı (Maarif Vekâleti) aracılığıyla kurulan Tercüme Bürosu çeviri yoluyla "toplumu aydınlatma, kültür düzeyini yükseltme, güzel bir Türkçe yaratma ve Türk edebiyatının gelişmesine katkıda bulunma, 'hümanizma' ruhunu canlandırma gibi

6 "milleti garbin [m]enafisi âsarı" 
hedeflerin ve işlevlerin gerçekleştirilmesi" amacını gütmektedir (Aksoy, 2000, s. 56). Dönemin Maarif Vekili Hasan Ali Yücel'e göre ise “(...) kaynağı ve pınarı eski Yunanla da tahdit etmeyip daha arkalara ve başka diyarlara gitmek, nerede insan ruhunun kendine göre mana taşıyan bir izi ve eseri varsa, onları da içine alarak en geniş kavramıyla Hümanizmayı bütün insanlığı kucaklayan bir anlayış" olarak görmek gerekmektedir (Yücel, 2011, s. 158). Yücel'in belirttiği üzere Tercüme Bürosu da bu hümanizma hareketinin çeviri ayağı kısmını oluşturmaktadır. Hasan Ali Yücel'in 1941-1946 yılları arasında devam eden vekilliği süresince Tercüme Bürosu vasıtasıyla birçok eser Türkçeye aktarılmıştır. Planlı hareket, dönemin cumhurbaşkanı İsmet İnönü tarafından da desteklenmiş, Maarif Vekaletinin kontrolündeki Maarif Basımevinden çıkan çeviri eserlere İnönü'nün bu hareketin arkasında olduğunu gösteren bir ön sözü eklenmiştir (Bk. Ek-4b):

Eski Yunanlılardan beri milletlerin sanat ve fikir hayatında meydana getirdikleri şaheserleri dilimize çevirmek, Türk milletinin kültüründe yer tutmak ve hizmet etmek istiyenlere en kıymetli vasıtayı hazırlamaktadır. Edebiyatımızda, sanatlarımızda ve fikirlerimizde istediğimiz yüksekliği ve genişliği bol yardımcı vasıtalar içinde yetişmiş olanlardan beklemek, tabii yoldur. Bu sebeple tercüme külliyatının kültürümüze büyük hizmetler yapacağına inanıyoruz. (Shakespeare (çev. Sevin), 1943, s. 3)

Dönemin çeviri hareketinin planlaması konusunda ortak çalışan Tercüme Bürosu ve Maarif Vekâleti, "yüksek satış rakamlarına ulaşmakla fazla ilgilen[memekte], daha çok, çeviri edebiyat dizgesi için planlanan repertuvara yönelik talep yaratmaya" çalışmaktadır (Tahir-Gürçağlar, 2018, s. 167). Bu talebi yaratırken de genellikle yazar kimliğinin yanında çevirmen kimliğiyle harekete katkıda bulunan Tercüme Bürosu çevirmenleri, bahsedilen planlı eylemin birer aktörü olmaktadır. 06.05.1939 tarihli Cumhuriyet gazetesinde, "Klasiklerin Yayını" başlığı altında Büronun Nurullah Ataç başkanlığında, üyeler Bedrettin Tuncel, Saffet Pala (Korkut), Enver Ziya Kara ile kurulduğu ve ardından Sabahattin Eyüboğlu'nun başkanlığında “Orhan Burian, Vedat Günyol, Azra Erhat, İrfan Şahinbaş, Nurettin Sevin, Melahat Özgü, Mehmet Farasan, Lütfi Ay, Ziya İshan, Nusret Hızır, Servet Lunel, Suat Sinanoğlu" gibi "bilim, kültür ve sanat insanları" nın üye olarak görev yaptığı bilgisi geçmektedir (Bk. Ek.1). Tercüme Bürosu'nun amacı bir bakıma 'yüksek edebiyat" olarak addedilen klasik eserlerin çevirisini destekleyerek yerli yazarları da Batı Edebiyatı'nın hümanizma ruhunu Türkiye'de yansıtacak eserler yazma konusunda yüreklendirmek (Karantay, 2008, s. 50; Tahir-Gürçağlar, 2015, ss. 67-71) ve "çeviri aracığıyla yüksek düzeydeki bir kültür iletişimini" kurmaktır (Erhat, 2008, s. 47). Saygın görülen edebi eserlerin çevirisini misyon edinen Tercüme Bürosunun bir diğer amacı da bu eserlerin ara dil olmaksızın kaynak dilden doğrudan çevirisini desteklemektir (BTNK, 1939, ss. 125-6). Nitekim doğrudan çeviri "büyük ölçüde" teşvik edilmiş, 1947 yılından itibaren Latince ve Yunanca gibi dillerden çeviri yapabilecek çevirmenlerin sayısının yetersizliği veya yoksunluğu sebebiyle ikinci dilden yapılacak ara dil çevirilerine de izin verilerek kaynak dilden doğrudan çeviri politikası konusunda fikir değişikliği yaşanmıştır (Karantay, 2008, s. 50; 
Tahir-Gürçağlar, 2018, ss. 150-2). Tahir-Gürçağlar'ın (2018, s. 151) aktardığı üzere yaşanan bu değişiklik dönemin bazı isimlerinin tepkisiyle karşılaşmıştır (Erhat, 1942, ss. 525-6; Sinanoğlu, 1941, s. 485; Ülken, 1942, s. 17). Devlet eliyle gerçekleştirilen Türkiye'nin en yoğun çeviri girişimi olduğu iddia edilebilecek Tercüme Bürosunun faaliyetleri (Aytaç, 1999, s. 348), 1946 yılında dönemin Maarif Vekili Hasan Ali Yücel'in istifası ile genel bir düşüş yaşamış, 1966 yılında Büro kapatıldığından çeviri faaliyetlerine son verilmiştir (Kayaoğlu, 1998; Tahir-Gürçağlar, 2015, ss. 74-6).

Gözetim ve denetimindeki çevirileri bugün hâlâ takdirle anılan ve bugünkü okuyucu kitlesi yadsınamaz olan Tercüme Bürosunun "nesiller üzerinde icra ettiği tesir" (Kayaoğlu, 1998, s. 200) ve "çeviri ve çevirmenlik mesleği ile ilgili bir bilinç yarattı̆̆ı" (Tahir-Gürçağlar, 2015, s. 115) aşikârdır. Çeviri etkinliklerinin hız kazandığı bu dönemde, her biri Türk çeviri edebiyat dizgesini oluşturmakta önemli role sahip üyelerce Tercüme Bürosunun yerleştirmeye çalıştığı üç norm, dönemin çeviri misyonunu özetler niteliktedir: "Saygın edebiyat alanında benimsendiğini gördüğümüz kaynak metin ve kaynak yazar vurgusu, doğrudan 'orijinal' dilden çeviri yapma gereği ve Latin alfabesiyle yazılan özel isimlerin yazılışlarının korunması" (Tahir-Gürçağlar, 2018, s. 369; Krş. BTNK, 1939, ss. 125-7). Çalışmanın bundan sonraki kısmında, Toury’nin "süreç öncesi çeviri normları"ndan hareketle dönemin planlama unsuru olarak ele alınan çevirinin (Krş. Toury, 2002), Sevin'in ön sözleri ışığında değişimin taşıyıcısı olma serüvenine tanıklık edilecektir.

\section{Kavramsal Çerçeve}

Çeviriyi çeviribilime taşıyan adım, James S. Holmes'un (1972) The Name and Nature of Translation Studies [Çeviribilimin Adı ve Doğası] adlı bildirisidir (Holmes, 2008). Böylelikle çeviribilim kendi kuram ve yöntemleri ile bir bilim dalı olma özelliğini kazanmıştır. Gideon Toury, "Çeviri Normlarının Doğası ve Çevirideki Rolü" adlı çalışmasında çeviriyi "kültür açısından önem taşıyan bir etkinlik", çevirmenliği ise "her şeyden önce toplumsal bir işlev üstlenme" olarak tanımlamaktadır (1995, s. 53). Bu toplumsal işlevi üstlenirken çevirmenin "birtakım 'norm'ları benimsemesi gerek"tiğini ifade eden Toury, belli bir kültür ortamında özümsenen normların çevirmenin davranışlarına dair saptama yapılabilmesi konusunda ipuçları verebileceğini ifade etmektedir (Toury, (çev. Eker), 2008, s. 149). Toury, çeviri normlarını "süreç öncesi normlar" ve "çeviri süreci normlar" olmak üzere iki ana başlık altında incelemiştir. "Süreç öncesi normlar" "çevirinin politikası" ve "doğrudanlığı" ile ilgili normları ele almaktadır. Çeviri süreci normları ise çeviri sürecinde metindeki eklemeleri, çıkarmaları kapsayan "matriks normlar" veya cümle diziliş ve öğeleri, sözcüklerle, deyişlerle ilgili kararları kapsayan "metinsel dilsel normlar"ı içermektedir (s. 154). Toury, ayrıca kaynak metnin/kaynak kültürün ya da hedef metnin/hedef kültürün normlarına yakınlığını betimleyen "öncül normlar"dan bahsetmiştir (ss. 152-3). Yalnızca erek odaklı ve betimleyici bir yaklaşımla gerekçelendirilebilecek olan bu saptamalarda "çeviri politikasının varlığı" ve "doğasına ilişkin" bilgiler içerdiğinden "süreç öncesi çeviri 
normları"nın "çeviri süreci normları karşısında hem mantıksal hem de kronolojik önceliği" bulunmaktadır (ss. 150-5). Çalışmanın kavramsal çerçevesini oluşturan "süreç öncesi normlar"ın "çeviri politikası" ve "çevirinin doğrudanlığı" kavramlarından bu kısımda söz edilecektir.

Toury, "süreç öncesi çeviri normları"nı iki ana başlık altında ele almaktadır: "çeviri politikası" ve "çevirinin doğrudanlığı". Çeviri politikası, "belirli bir zamanda belirli bir kültüre/dile çeviri yoluyla ithal edilecek metin türlerinin seçimini, hatta tek tek metinlerin seçimini içermektedir. Söz konusu seçimin rastgele yapılmadığı bulgulandığı sürece ise böylesi bir politikanın var olduğu düşünülür" (s. 153). Çevirinin doğrudanlığı ise aşağıdaki gibi sorulara yanıt vermeyi amaçlamaktadır:

Hangi kaynak dillerden/metin türlerinden/dönemlerinden çeviri yapılması(na) izin verilmektedir?"; "Hangi kaynak/ara dillerden çeviri yapılması(na) izin verilmektedir/ yasaklanmıştır/ hoş görülmektedir/ tercih edilmektedir?"; "İzin verilen/yasaklanan, hoş görülen/tercih edilen aracı diller hangileridir?"; "Bir çevirinin ara dilden yapıldığının belirtilmesi eğilimi/zorunluluğu var mıdır?"; "Yoksa bu gerçek göz ardı/kamufle/ inkâr mı edilmektedir?"; "Eğer aracı bir dilin varlığından söz ediliyorsa, aracı dilin hangisi olduğu da bildirilmekte midir?" (s. 154).

Toury bütününde, ürün odaklı fakat süreci reddetmeyen, erek odaklı ve aynı zamanda kaynağa da yer veren, tarihsel ve bununla birlikte eşsüremli ve açıklamayı amaçlayan betimleyici bir yaklaşım öne sürmektedir (Krş. Bengi-Öner, 2008, s. 164). Çeviribilimin betimleyici doğası konusunda doğru/yanlış gibi değer yargılarından uzak bir tanımlamaya giden Toury'nin yaklaşımı (1995, s. 2), nesnellik arayışı sebebiyle insan, kültür, ideoloji gibi unsurları göz ardı ettiği yönünde bazı eleştirilere maruz kalmıştır (Krş. Niranjana, 1992; Pym, 2014; Spivak, 2012; Venuti, 1998). Toury'nin çeviriyi erek odağa konumlandıran betimleyici yaklaşımı her ne kadar çeviriyi nesnel ölçütlerle ele aldığına yönelik eleştiriler ile karşılaşsa da çeviribilimi görgül bir bilim dalı olarak sunan bu yaklaşım, aynı zamanda "açıklayıcı"dır (Toury, 1995, s. 15). Çeviri ise toplumsal ve kültürel bir etkinliktir (Krş. Toury, (çev. Eker), 2008). Dolayısıyla görgül çeviribilim alanının açıklamayı amaçlayan, gözlemlenebilir olanı ele alan betimleyici yaklaşımı, içinde "kültürel ve toplumsal bağlamların güç ilişkilerini de içeren" (Tahir-Gürçağlar, 2015 , s. 26), üst alanlarla zenginleşerek "geniş ölçekli bakış açısı" oluşturabilir (BengiÖner, 2008, s. 172).

Özellikle "çevirmenlerin birçoğu"nun "etkinlikleri aracılığıyla" çeviri normlarında gerçekleşen değişim sürecinin "şekillenmesine katkıda bulun"duğu savından hareketle (Toury, (çev. Eker), 2008, s. 156), "asıl gözlemlenebilir olan (...) normların yönlendirdiği davranış örnekleri", yani, "bu tür davranışların ürünleri"ni (Toury, (çev. Eker), 2008, s. 158) inceleyebilmek için ihtiyaç duyulan davranış örneklerinden biri de çevirmenlerin kendi yazdıkları ön sözlerdir. Zira doğrudan gözlemlenmesi mümkün olmayan "süreç öncesi çeviri normları"na ilişkin bilgilerin, 
çevirmenin kendi davranışlarını, kendi ağzından açıkladığı çevirmen ön sözlerinde bulunacağı tahmin edilmektedir (Krş. Toury, (çev. Eker), 2008, s. 158).

\section{Yöntemsel Yaklaşım: Ön Sözlerin "Süreç Öncesi Çeviri Normları" Bağlamında İncelenmesi}

Çalışmanın inceleme nesneleri oluşturulurken ilk etapta Nurettin Sevin'in çevirdiği eserlerin bir taraması yapılmış ve kendisinin 11 çeviri eserine ulaşılmıştır. Ardından bu çeviri eserler, çevirmen ön sözü bulunanlar, çevirmen/yayınevi sahibinin ön sözü bulunmayanlar ve yayınevi sahibinin ön sözü bulunanlar şeklinde sınıflandırılmıştır. Aşağıda çeşitli katalog taramalarıyla ${ }^{7}$ ulaşılan Nurettin Sevin'in çevirisini yaptığı eserlerin detaylı sınıflandırması verilmiştir.

Çevirmen/Yayınevi Sahibi Ön Sözü bulunmayan çeviri eserleri:

- Bir Yaz Dönümü Gecesi Rüyası (Shakespeare, 1944, Maarif Matbaası)

- Caesar'la Kleopatra (Shaw, 1945, Milli Eğitim Basımevi)

- $\quad$ Tiyatro Sanatı Hakkında (Craig, 1946, Milli Eğitim Basımevi)

- Hırçın Kız (Shakespeare, 1946, Milli Eğitim Basımevi).

Yayınevi Sahibinin ${ }^{8}$ Ön Sözü bulunan çeviri eserler:

- Salomé (Wilde, 1935, Hilmi Kitabevi)

- Yaz Ortasında Bir Gecelik Bir Rüya (Shakespeare, 1936, Hilmi Kitabevi).

Çevirmen Ön Sözü bulunan çeviri eserler:

- Bahtiyar Prens ve Başka Masallar (Wilde, 1938, Hilmi Kitabevi)

- $\quad$ Narlı Ev (Wilde, 1939, Hilmi Kitabevi)

- Venedik Taciri (Shakespeare, 1943, Maarif Matbaası)

- Ehemmiyetsiz Bir Kadın (Wilde, 1948, Milli Eğitim Basımevi)

- Julius Caesar (Sezar) (Shakespeare, 1942/1958, Maarif Basımevi).

Çalışmanın bu bölümünden itibaren Nurettin Sevin'in 11 çevirisinden yalnızca kendisinin çevirmen ön sözü yazdığı 5 çeviri eserin ön sözü Toury'nin "süreç öncesi normları" kapsamında, "çeviri politikası" ve çevirinin doğrudanlığı" başlıkları altında irdelenecektir" . Bu eserlerden üçünün yazarı Oscar Wilde, ikisinin yazarı ise William Shakespeare'dir.

\section{1 "Çeviri Politikası"}

Bu kısımda Nurettin Sevin'in yazdığı çevirmen ön sözleri, Gideon Toury’nin “süreç öncesi çeviri normları"ndan "çeviri politikası" kavramı kapsamında irdelenecektir.

\subsubsection{Bahtiyar Prens ve Başka Masallar}

\footnotetext{
${ }^{7}$ Bu verilere erişilirken Milli Kütüphane Katalog Tarama, Ulusal Toplu Katalog ve üniversite kütüphanelerinden faydalanılmıştır.

${ }^{8}$ Hilmi Kitabevi sahibi İbrahim Hilmi Çığıraçan tarafından yazılan ön sözlerdir.

9 Ön söz, son söz, notlar, reklam ve tanıtım yazılarından alınan tüm alıntılar, orijinalinde olduğu gibi aktarılmıştır.
} 
Oscar Wilde tarafından kaleme alınan Bahtiyar Prens ve Başka Masallar, Nurettin Sevin çevirisiyle 1938 yılında Hilmi Kitabevi tarafından basılmıştır. Nurettin Sevin çevirdiği bu esere 16 sayfalık bir ön söz yazmış ve ön sözünde çeşitli başlıklar altında yazar, yazarın sanatı ve eserin ehemmiyeti, tercüme meselesi gibi konularda görüşlerine yer vermiştir. Sevin, "Okuma merakının artması ve münekkitlerin şikâyeti” başlığında (Bk. Ek-2a), tercümenin bir sisteme tabi olması gerektiğinden aksi takdirde okuyucunun, çevirmenin eline geçen her kitabı çevirmesini doğru bulmayacağından bahsetmiştir (Wilde (çev. Sevin), 1938, s. 5). Sevin'in sözlerinden, kendisinin "çeviri yoluyla ithal edilecek metin" (Toury, (çev. Eker), 2008, s. 153) seçimini yaparken belirli bir çeviri politikasını sahiplendiği yönünde çıkarım yapmak mümkündür. Nitekim Wilde'ın eserlerine ahlak vurgusuyla yüklenenlere, ahlakın şüphesiz insanlık için önemli olduğunu belirterek "bütün sanat eserlerini ahlâk süzgecinden geçirecek olursak süzgeç deliklerinden acaba san'at sızabilir mi?” sorusuyla cevap vermiştir (Wilde (çev. Sevin), 1938, s. 8; Bk. Ek-2b).

Wilde'ın üslubunun yüceliğinden ve sanatının güzelliğinden söz ederken tercüme ile telif eseri birbiri ile kıyaslamaktadır: "terceme işi de telif kadar titizliğe layıktır kanaatindeyim. Hatta belki teliften daha ziyade itinaya değer; çünki telifte muharririn kendi üslûbu, ifadesi, çeşnisi zaten mevcuttur, akar gider; fakat tercemede vazıyet büsbütün başka türlüdür" (Wilde (çev. Sevin), 1938, s. 14; Bk. Ek-2c). Bu sözleri ile Sevin, çeviri konusundaki titizliğini gözler önüne sermektedir. Sözlerinin devamında, tercümenin kaynak metindeki üslup ve sanatı hedef dilde yaşatması gerektiğini vurgulamıştır: “(...) her muharririn kendi üslûbunu, kendi ifadesini, kendi zevkini, kendi çeşnisini çevirdiğimiz dilde yaşatmak ve yadırgatmamak mutlaka zarurîdir. Aksi takdirde terceme mevzuun naklinden başka bir şey ifade etmez" (Wilde (çev. Sevin), 1938, s. 14; Bk. Ek-2c). Ön sözünün son cümlesinde kendisinin bir çevirmen olarak bu konuda gösterdiği çabayı belirterek bitirmiştir: "Her halde ingilizcesine sadık kalmak hem de aynı zevkı verebilmek için yapabileceğimin son haddine kadar uğraştım. Bu da aynı muvaffakiyeti kazanırsa ne mutlu" (Wilde (çev. Sevin), 1938, s. 16; Bk. Ek-2d). Sevin'in kaynak metnin seçimine ve özellikle bu metnin yazarına gösterdiği önemin çevirmen Sevin'in “çeviri politikası”na ilişkin ipuçları verebileceği görülmektedir.

\subsubsection{Narlı Ev}

Narlı Ev, Hilmi Kitabevinin yayımladığı, dış kapağında yazar Oscar Wilde ve çevirmen Nurettin Sevin'in isminin yan yana olduğu, kapağı resimli çeviri bir eserdir (Bk. Ek-3a). Kitabın arka kapağında "FIATI 40 KURUŞ" şeklinde bir ibare bulunup bunun altında "Ingiliz Edebiyatından Tercümeler" başlığı yer almaktadır. Hilmi Kitabevinin bastığı kaynak dili İngilizce olan çeviri eserler, çevirmenleri ve fiyatlarıla birlikte burada yer almaktadır. İç kapak sayfasında "Oscar Wilde ve arkadaşı" başlıklı Oscar Wilde'a ait tam sayfa bir fotoğraf (Bk. Ek-3b) bulunmakla birlikte bir sonraki sayfada "Çeviren: Nureddin Sevin" ibaresi bulunmaktadır.

Sevin, Narlı Ev çevirisinde de çeşitli alt başlıklarda Oscar Wilde ile ilgili çeşitli anekdotlara değinmiştir. "Estetik üstadı Oscar Wilde" ana başlığını verdiği çevirmen ön 
sözü (Bk. Ek-3c), "Narlar", "Eserin ismi”, Wilde'ın estetik mektebının menşei”, "Oxford Günleri", "Tedkik ve Tecrübeleri", "Estetik kostüm" şeklinde devam eden on üç alt başlıkla oluşturulmuştur. Sevin, Bahtiyar Prens ve Başka Masallar'da olduğu gibi, Narlı $E v^{\prime}$ de de Türk edebiyat dizgesine yazarı tanıtma niyetiyle Oscar Wilde'dan "meşhur estetik üstadı" ifadesiyle bahsetmekte ve Narlı Ev'de de bu üstadın sanatından bahsetmenin genç okuyucular için faydalı olacağını düşündüğünü dile getirmektedir (Wilde (çev. Sevin), 1939, s. 3). Ardından eserin tercümesinde anlamdan ziyade ses ahengine önem veren bu üstadın Türk lisanına tercüme edilmesi konusunda titiz davrandığını vurgulamaktadır. Özellikle eserin başlığının tercümesi konusundaki kararsızlığını, "Narlardan bir Ev" desem Türkçede ahengin değil tenafürün timsali olurdu. "Nardan bir Ev" desek fazla gürültülü, "Nar Ev" de pek yavan geldi. "Narlı ev" Wilde'ın ifade etmek istediği gizli manâyı da tazammun edebilir" (Wilde (çev. Sevin), 1939, s. 4; Bk. Ek-3d) örnekleriyle açıklamaktadır. Sevin'in ön sözünde hem kaynak metnin yazarına hem de çeviri kararlarına ayırdığı geniş bölüm, çeviri politikasının rastgele seçimlerden ibaret olmadığının açık bir göstergesidir.

\subsubsection{Venedik Taciri}

Nurettin Sevin'in William Shakespeare'den çevirdiği 1943 yılında Maarif Matbaası tarafından yayımlanan Venedik Taciri'nin iç kapak sayfasında çevirmenden "Siyasal Bilgiler Okulu İngilizce öğretmeni Nureddin SEViN" ifadesiyle söz edilmiştir (Bkz. Ek-4a). Tercüme Bürosunun genel olarak çevirmenlerinin büyük çoğunluğunun üniversitede veya orta öğretim kurumlarında ders veren öğretmenler olması da "klasiklerin çevirisinin eğitimle yakın ilişkisini gösteren bir noktadır" (Tahir-Gürçağlar, 2018, s. 146). Çevirmen Nurettin Sevin de eğitimci kimliği ile bunun bir örneğidir.

Ardından Tercüme Bürosundan çıkan çevirilerde görülen bir uygulama ile karşılaşılmaktadır. Dönemin Maarif Vekili Hasan Ali Yücel'in "Hümanizma" ruhu ve bu ruhun Türk edebiyat dizgesinde canlandırılmasına vesile olan tercüme faaliyetinin önemi ve tercüme edilecek eserlerin seçiminin önemi üzerine yazdığı ön söz okuyucuya seslenmektedir (Bk. Ek-4c): "Hümanizma ruhunun ilk anlayış ve duyuş merhalesi insan varlığının en müşahhas şekilde ifadesi olan sanat eserlerinin benimsenmesiyle başlar (...) Işte tercüme faaliyetin, biz, bu bakımdan ehemmiyetli ve medeniyet dâvamız için müessir bellemekteyiz" (Shakespeare (çev. Sevin), 1943, s. 7). Hasan Ali Yücel'in ön sözü sonrasında, Nurettin Sevin, Venedik Taciri'ne 14 sayfalık bir ön söz yazmıştır. Bu ön sözde William Shakespeare'in sanatının ve üslubunun güzelliğinden bahsetmekte ve çevirmenlerin Shakespeare'in eserlerindeki yazım tarzında asla "düzeltmeye" gitmemesi gerektiğini savunmaktadır: "Cümlelerini eksik zannedip tamamlamak için ömür tüketenlere o yanlışları kasten yaptığını niçin akla getirmezler?” (Shakespeare (çev. Sevin), 1943, s. 10). Çünkü Sevin'e göre Wilde, bir cümleyi eksiltili bıraktıysa da bu yaptığı yanlıştan değil sanatının yüceliğindendir ve o şekilde dilimize aktarılması gerekmektedir. Çevirmenin yazara ve kaynak metne gösterdiği itibar ve özene örnek olarak gösterilebilecek bu düşüncenin izdüşümü, ön söz boyunca devam etmektedir. Son 
olarak, Venedik Taciri'nde sıklıkla karşılaşılan kafiyeli kısımların çevirisine ilişkin Sevin'in okuyuculara uyarı niteliğinde bir açıklaması bulunmaktadır:

İşte bu maksatla Shakespeare'in kafiyesiz nazımla yazdığı en büyük kısmı kafiyesiz vezinle tercüme etmeyi ona yaklaşmak için en doğru yol bulduk; yalnız okullarımızda nazım kuyu çıkrığı takırtısiyle, yahut muayyen kararlı inlemelerle okunmasına, daha doğrusu terennüm edilmesine alıştığı için mısraları alt alta yazmaktansa, tıpkı nesir gibi yan yana yazıp vezni gizlemeyi tercih ettik; bizde de inşadıgarpta olduğu gibi, kelimeler öz ve hakiki ahengine dayanacağı güne kadar bu en tehlikesiz bir yoldur; okuyucunun zahmet edip vezni aramasına hiç lüzum yoktur, o, kelimelere cümlelere yükselişi alçalışı tertiplere nizam vermek için yalnız yazanı alâkalandıran bir şeydir: Shakespeare'e yaklaşmak istiyen vezinleri, kafiyeleri, takırdatmamalı, kelimelerin öz manalarını yaşatmalıdır. (Shakespeare (çev. Sevin), 1943, ss. 13-4)

Burada da çevirmenin kaynak metne ve bu metnin yazarına gösterdiği itibarı görmek mümkündür. Sevin, Shakespeare'in sözcükleri kullanım şeklinin eşsizliği ve üslubunun ahengini özellikle vurgulamıştır. Kendisinin çeviri politikasındaki titizliğinin ve kararlılığının da ön sözünde ısrarla üzerinde durduğu vurgulamalardan çıkarılabileceği söylenebilir.

\subsubsection{Ehemmiyetsiz Bir Kadın}

Oscar Wilde’ın eseri Ehemmiyetsiz Bir Kadın, 1948 yılında Milli Eğitim Basımevi tarafından Nurettin Sevin çevirisiyle yayımlanmıştır. Çevirmen Sevin, daha önce kendisine Salomé yi tercüme ettiren sebeple Ehemmiyetsiz Bir Kadın'ı tercüme ettiren sebebin aynılığından bahsetmiştir: "Wilde'ın sanatlı tiradları ve ahenkli üslubu". Böylelikle Sevin, çevireceği eserin seçimindeki iradesini ve dolayısıyla çeviri politikasının varlığını ortaya koymaktadır. Okuyucunun veya eleştirmenlerin bu eserlere bakarken tüm bunların farkında olması gerektiğini ifade etmektedir:

Bundan yirmi dört sene evvel bana onun Salomé'sini tercüme ettiren en büyük sebep, tarihin Herod'uyla hiçbir münasebeti olmıyan o sanatlı tiradlarla, İncilin mâkul ve mantıki vaızı Vaftizci Yahya'sını bir meczup şair haline sokan muhteşem saçmalardı. Bunların hakikatle, tarihle, tabiilikle hiç alâkası olamazdı. Bunlar, sanatın öz mahsulleri oldukları için, bizi hayran bırakıyordu. İşte bunun için geçen asrın yanlış kültürüne dayanan yabancı dürbüniye Wilde'ın eserlerine bakanlar onda hiçbir şey bulamazlarsa kabahat Wilde'de değil o ters gösteren dürbündedir. (Wilde (çev. Sevin), 1948, s. 3; Bkz. Ek-5c)

Sevin'in ön sözünde kendi ifadesiyle belirttiği üzere, metin seçimindeki titizliği ve bunun sebebini açıklama biçimi, "çeviri politikası”na ilişkin doğrudan bilgi vermektedir.

\subsubsection{Julius Caesar}

Nurettin Sevin'in Shakespeare'den çevirdiği 1942 yılında ilk baskısı yapılan bu eserde çevirmen ön sözü bulunmamaktadır. Eserin ikinci baskısında çevirmen ön sözü olduğu tespit edilince, inceleme nesnelerine ikinci baskı dâhil edilmiştir. Julius Caesar'ın ikinci 
baskısı, Maarif Basımevi tarafından 1958 yılında yayımlanmıştır. Eserde Sevin'in çevirdiği diğer eserlere nazaran farklı olan önemli bir ayrıntı dikkat çekmektedir. İç kapak sayfasından sonraki sayfada "Bu eser, Güzel Sanatlar Umum Müdürlüğü tarafından açılan müsabakaya gönderilen tercümeler arasında Vekillik tercüme Bürosu'nca incelenerek birinci seçilmiştir" yazısı (Bk. Ek-6b) göze çarpmaktadır. Bu yazı, çeviri eserin dönemin çeviri edebiyat dizge planlamasını yapan Tercüme Bürosu gibi üst bir denetim mekanizması tarafından birinci seçilerek takdir gördüğünü ve okuyucuya eserin çevirisinin ne denli değerli bulunduğunu vurgulamaktadır. Bu bilgilendirici yazı, okuyucuya çeviri eserin ve dolayısıyla çevirmen Nurettin Sevin'in gördüğü rağbeti yansıtmaktadır. Çevirmen ön sözünde ise, Sevin, daha önce yazdığı çevirmen ön sözlerinde olduğu gibi Julius Caesar' da da yazar Shakespeare'in sanatının üstünlüğünden bahsetmektedir: "Shakespeare'in seyirci hisleriyle oynaması, onları yerden yere sürüklemesi bütün tiyatro yazarlarına bir derstir. Onun için hakikat ancak san'attir. Oyunun başından sonuna kadar nefret ettiğiniz, diş gıcırdattığınız adama oyunun sonunda acımanız, ağlamanız lâzım. Shakespeare işte bunun üstadıdır" (Shakespeare (çev. Sevin), 1958, s. 9) şeklindeki övgüsü Sevin'in kaynak metnin yazarı Shakespeare'e olan hürmet ve rağbetinin açık bir göstergesidir. Sevin, yazdığı ön sözde, çevirmen kimliğinin yanı sıra tiyatro hocalığı kimliğiyle de görünürdür. Sözlerinin devamında, muhtemelen kendisinin Devlet Konservatuvarı öğretmeni olması, tiyatro öğrencilerine diksiyon dersleri vermesi ve hatta Devlet Konservatuvarı Tiyatro Bölüm Şefliği görevinde bulunması sebebiyle, Shakespeare'in tiyatro eserlerindeki her bir sözcüğün önemini ve gerekliliğini işaret etmektedir: (Bk. Ek-6c): "Shakespeare, eserini ancak tiyatro gayesiyle yazardı, o kadar o maksatla yazardı ki eserlerinde birinci derece ehemmiyeti olmıyan bir tek kelime bulmak kolay değildir" (Shakespeare (çev. Sevin), 1958, s. 11). Hatta Shakespeare'i tiyatro eserlerinde anlamanın öncelikli yolunu ifade ederken Shakespeare'in "her şeyi ne kadar bilerek yaptığını, duyurduğunu ne kadar duyarak işlediğini anlamak için onda harcıâlem ilmî hakikatler aramaktan vazgeçip, bütün eserlerini ilk sözlerinden son sözlerine kadar, başlı başına müstakil bir ilim olan tiyatro tekniğinin ve his fırtınalarının huzmesinden geçirmek lâzımdır" sözleriyle Shakespeare'in eserlerini tiyatro tekniği ve duygu süzgecinden geçirmenin önceliğinden bahsetmektedir (Shakespeare (çev. Sevin), 1958, s. 18; Bk. Ek-6d).

Sevin'in, Shakespeare'in diksiyon konusundaki hassasiyetine dair övgüleri, "Shakespeare'in bugün Diksiyon dediğimiz, söz tekniğine ne kadar meraklı olduğunu anlamak için 1623 de, yani ölümünden yedi yıl sonra çıkan ilk Folio tab'ından alınan şu sayfaya bakmak kâfidir" (Shakespeare (çev. Sevin), 1958, s. 15) satırlarından anlaşılmaktadır. Zira bu satırların ardından çevirmen ve diksiyon eğitimcisi Sevin, Julius Caesar'dan metin içi örneklerle Shakespeare'in özenli noktalamasına, telaffuz ve diksiyon konusundaki titizliğine işaret etmektedir.

Bu sebeplerden, Sevin'in Shakespeare'den çevirdiği Julius Caesar'da da metin seçiminin rastgele yapılmadığı, dolayısıyla bir çeviri politikasının var olduğu bulgusuna rastlandığı ifade edilebilir. 


\section{2. "Çevirinin Doğrudanlığı"}

Bu kısımda Nurettin Sevin'in yazdığı çevirmen ön sözleri, Gideon Toury’nin “süreç öncesi çeviri normları"ndan "çevirinin doğrudanlı̆̆ı" kavramı kapsamında irdelenecektir.

\subsubsection{Bahtiyar Prens ve Başka Masallar}

Nurettin Sevin, Bahtiyar Prens ve Başka Masallar'ın ön sözünde "Terceme meselesi" başlığı altında Wilde'ı bir ara dilden çevirmenin çevirmene pahasını, "San'atı sırf san'at gözile gören Oscar Wilde'ın eserlerinde her cümle hesaplı, her söz ölçülüdür. Seçme sözlerinde telaffuzunu beğenmediği kelimeleri kullanmaz, iğrenç müptezel sözlerle hiç bağdaşamaz. İşte bu itibarla onu ikinci bir dilden terceme etmek çok şey kaybettirir" (Wilde (çev. Sevin), 1938, s. 14; Bk. Ek-2c) şeklinde ifade etmiştir. Ön sözün devamında ise "bir eserin ikinci bir lisandan tercemesi çok şey kaybettirir" (Wilde (çev. Sevin), 1938, s. 15) diyerek ara dil çevirisinin makbul olmadığı düşüncesini, yalnızca Wilde'ın eserleri için değil herhangi bir eser için ortaya atmaktadır. Sevin, "Bir mütercim nihayet mahdut bir kaç imzanın üslubûna yaklaşabilirken, tercemenin tercemesine kalkmak bütün bu lüzumlu muvaffakiyet unsurlarını hiçe saymak olur" (Wilde (çev. Sevin), 1938, s. 15) sözleri ile hem çevirmenlik mesleğinin ciddiyetinin hem de çeviri işinin ne denli meşakkatli olduğunun altını çizmektedir. Üstelik ara dilden çeviri konusuna bakış açısını da apaçık bir şekilde dile getirmektedir. Sevin'e göre çeviri işinin hakkını veren bir çevirmen sınırlı da olsa birkaç yazarın kalemine yaklaşabiliyorken çevirinin çevirisi olan ara dilden yapılan çevirilerden aynı başarıyı beklemek imkansızdır.

Sevin, ara dilden çeviri hakkındaki olumsuz görüşünü farklı dillerden gerçekleştirilebilecek ara dil çevirilerinden örnekler vererek desteklemektedir: "Fransızca yazılmış bir eserin İngilizceden, aslı Rusça olan bir romanın Fransızcadan tercemesi elbette çok sakat ve muzirdir" (Wilde (çev. Sevin), 1938, s. 15). Hatta kendisinin "tercemede muvaffakiyet göstermiş kalemler" olarak bahsettiği Suut Kemal Yetkin, Gaffar Güney, Senika Köknil'in "doğrudan doğruya”, "asıllarından duyarak terceme ettiğini"ni dile getirmektedir. "ikinci bir lisandan terceme edildiği halde" Sevin'in başarılı bulduğu çeviriler de yok değildir fakat kendisi, "bazı eserler[i] Tercemenin tercemesi olmasa elbette muharririn ruhuna ve san'atına daha ziyade nüfuz etmek imkânını bulurlardı" izahıyla yine de "doğrudan" çeviriyi ara dil çevirisine kıyasla yazara "ayna" olmak konusunda daha olumlu karşıladığını işaret etmektedir. Kendisinin "metnin asıl kaynak dilinden başka, aynı metnin farklı dillerden de çevrilmesine karşı tanınan hoşgörü eşiği”nin (Toury (çev. Eker), 2008, s. 154) oldukça düşük olduğu iddia edilebilir. Bu örneklerden Sevin'in, Wilde'ın kendine özgü üslubunun nazarında aslında herhangi bir eserin de ikinci bir dilden çevirisini makbul görmediği anlaşılmaktadır.

\subsubsection{Narlı EV}

Çevirmen ön sözünde "çevirinin doğrudanlığı" ile ilgili açık bir ifade geçmemektedir. Fakat Nurettin Sevin, "geçen sene neşredilen Bahtiyar Prensin de mukaddimesinde bu meşhur estetik üstadının san'at telakkilerinden, kendi yazılarına istinat ederek 
bahsetmiştim" (Wilde (çev. Sevin), 1939, s. 3) diyerek Wilde'ın bir diğer eseri olan Narlı $E v^{\prime}$ de de Oscar Wilde ile ilgili yazdıkları konusunda aynı düşüncede olduğunu belirtmektedir. Sevin, Narlı Ev'in çevirisini de doğrudan İngilizceden yapmış ve Wilde'ı ara dilden çevirmek konusundaki düşüncelerini bir yıl önce yine Hilmi Kitabevinden çıkan Bahtiyar Prens ve Başka Masallar'da açıkça belirtmiştir. Dolayısıyla, "çevirinin doğrudanlı̆̆ı" kapsamında Narlı Ev'de de ara dil çevirisi yerine kaynak dilden doğrudan gerçekleştirilen çeviriyi tercih ettiği görülmektedir.

\subsubsection{Venedik Taciri}

Nurettin Sevin'in William Shakespeare'den dilimize çevirdiği Venedik Taciri'nin ön sözünde, Sevin'in "Siyasal Bilgiler Okulu İngilizce Öğretmeni” olduğu (Bk. Ek-4a) kitabın iç kapak sayfasında vurgulanmıştır. Çevirmen ön sözünde ise Sevin, sahnelenmek üzere yazılan Venedik Taciri'nde, oyuncuya yardımcı olmak için tercümeyi eserin aslına benzetmenin daha faydalı olacağını ifade etmiş ve özelikle "Fransız mütercimlerinden görebildiklerim bu noktalamaya hemen hiç riayet etmemiş" (Shakespeare (çev. Sevin), 1943, s. 12) oldukları şeklinde ara dilden çeviri yapan mütercimlere serzenişte bulunmaktadır. Ardından, Shakespeare ve sanatına yaklaşmanın en iyi yolunun tercüme olduğundan söz edip kaynak dilden doğrudan çeviri yaparken de titiz olunması gerektiğini vurgulamaktadır: "ona tercüme yoliyle yaklaşmak ancak onun her devrini o devrenin karakterine göre tercüme etmeye girişmekle kabil olur" (Shakespeare (çev. Sevin), 1943, s. 12; Bk. Ek-4d). Bu vurgulamalar, kaynak dilden yapılan doğrudan çevirilerin makbul görüldüğüne dair bir kanıt olarak gösterilebilir.

\subsubsection{Ehemmiyetsiz Bir Kadın}

Sevin'in İngilizceden dilimize aktardığı Oscar Wilde'ın Ehemmiyetsiz Bir Kadın adlı eseri de kaynak dilden doğrudan yapılmış bir çeviridir. Sevin, Oscar Wilde ile ilgili düşüncelerini izah ederken "onun sanat telâkkileri hakkında başka vesilelerle yazdığım şeyleri bu kitabın önsözünde tekrarlamak istemiyorum" diyerek daha önce Wilde'ın yazarı olduğu Bahtiyar Prens ve Başka Masallar ve Narlı Ev çevirilerinde yazdığı ön sözlerdeki düşüncelerine göndermede bulunmaktadır (Wilde (çev. Sevin), 1948, s. 1). Dolayısıyla, kendisinin daha önce çeviri eserlerinin ön sözlerinde belirttiği gibi ara dil çevirisine sıcak bakmadığı ifade edilebilir.

\subsubsection{Julius Caesar}

Shakespeare'in Ingilizce yazdığı Julius Caesar da Nurettin Sevin tarafından kaynak dilden doğrudan yapılmış bir çeviri örneğidir. Sevin'in daha önce ara dilden yapılan çevirilere ilişkin görüşlerine ek, kitabın sonunda “NOTLAR ŞERHLER VE iZAHLAR" başlığı altında yazdığı Julius Caesar çevirisindeki çeviri kararlarına ilişkin 53 sayfalık not (159-212), çeviri konusundaki hassasiyetinin ve söz konusu seçimleri rastgele yapmadığının bir örneğidir. Sevin'in bu kısımda, II. Perdedeki 21. notundaki “Fransızca tercümelerde Annoy'u bugünkü mânasına göre almışlar, endişeye düşürmeden, hiddetlendirmeden gibi. Halbuki mânası: without hurting: dokunmadan" (Shakespeare (çev. Sevin), 1958, s. 167) ve 237. 
notunda "Fransızcasında bu nokta düşünülmemiş, aux funerailles da âdeta mücerret ve hürmetkârane bir lisan kullanılmış" (Shakespeare (çev. Sevin), 1958, s. 189) şeklindeki açıklamaları incelendiğinde, kendisinin Fransızcadan gerçekleştirilen ara dil çevirilerine yönelik düşüncelerine dair ipuçları bulmak mümkündür. Ayrıca 100.notundaki, "Fransızca tercümesinde burası tahrif edilmiş" (Shakespeare (çev. Sevin), 1958, s. 179), III. Perdedeki "132.notunda "Fransız mütercimler bunu yanlış anlamış" (Shakespeare (çev. Sevin), 1958, s. 195) ve son olarak da V. Perdedeki "Gördüğüm Fransızca tercümelerde hep several'ı atlamışlar, bu çünki mânasını düşünürsek bir şey anlamak kabil olmaz, halbuki Elizabeth devri İngilizcesinde several kelimesi separate, distinct, different mânalarına gelirdi" (Shakespeare (çev. Sevin), 1958, s. 211) şeklindeki eleştirilerinden de Fransızcadan gerçekleştirilen ara dil çevirileri hakkındaki görüşlerinin olumsuz olduğu iddia edilebilir.

\section{Sonuç Gözlemleri}

Çevirmen Nurettin Sevin'in çevirilerine yazdığı ön sözler tanıklığında, çevirmenin çeviri politikasına dair izlenimde bulunmak amacıyla gerçekleştirilen bu çalışmada, Nurettin Sevin'in çevirilerine yazdığı ön sözler, Gideon Toury'nin "süreç öncesi çeviri normları" çerçevesinde incelenerek çevirmenin eser/yazar seçimini belirleyen etkenler, "çeviri politikası" kavramı, çevirinin gerçekleştiği ara dil/kaynak dil ise "çevirinin doğrudanlığı" kavramı kapsamında araştırılmıştır.

Çalışmada incelendiği üzere, Sevin'in çevirilerini yayımlayan Tercüme Bürosunun kendi hazırladığı raporda ve bu dönemde Tercüme Bürosu ile çalışan çevirmenlerin görüşleri ile uyumlu olarak mümkün olduğunca kaynak dilden doğrudan çeviriyi makbul gördüğü ve hümanizm ilkesi doğrultusunda saygın görülen klasik eserlerin çevirilerini teşvik ettiği saptanmaktadır (Krş. Aksoy, 2000; Tahir-Gürçağlar, 2015; Erhat, 2008; Karantay, 2008; Yücel, 2011). Benzer şekilde Nurettin Sevin'in çevirilerinin yayımlandığı özel bir yayınevi olan Hilmi Kitabevinin sahibi İbrahim Hilmi Çı̆̆ıraçan'ın de çeviri yoluyla Batı edebiyatından ithal edilecek eserlerden milletin faydasına olanların dilimize kazandırılması yönünde bir çeviri politikası izlediği görülmektedir (BTKN, 1939, s. 377).

Çalışmanın başlıca inceleme nesneleri olan Nurettin Sevin'in çevirilerine yazdı̆̆ı ön sözlerin tanıklığında, çevirmenin "normların yönlendirdiği bir etkinlik olarak çeviride" (Toury (çev. Eker), 2008, s. 153), çeviri ürünün davranış örneği olan ön söz yazımına önem verdiği tespit edilmiştir. Sevin'in çevirilerine yazdığı tüm ön sözlerin ışığında, "çeviri politikası" göz önünde bulundurulduğunda, çevireceği edebî türdeki metinlerin saygın görülen eserler ve bu metinlerin yazarlarının aynı şekilde saygın kabul edilen yazarlar arasından olmasına dikkat ettiği ön sözlerindeki ifadelerinden net bir biçimde anlaşılmaktadır (bkz. Bahtiyar Prens ve Başka Masallar, Narlı Ev, Venedik Taciri, Ehemmiyetsiz Bir Kadın ve Julius Caesar). Çevirmen Sevin'in, eserlerin çevirisini yaparken yazarın sanatlı ve ahenkli dilini korumak için elinden gelen özeni gösterme niyetinde olduğu ve çevireceği metnin seçimini rastgele yapmadığı ifade edilebilir. Dolayısıyla, 
çevirmen Sevin'in kendi yazdığı ön sözler tanıklığında çeviri politikasının rastlantısal olarak değil de bilinçli bir şekilde benimsendiği iddia edilebilir. Nitekim, Sevin'in ön sözlerinin tanıklığında benimsediği çeviri politikasının hem Hilmi Kitabevi ile hem de Tercüme Bürosu ile çalışırken örtüştüğü söylenebilir.

"Süreç öncesi çeviri normları"ndan "çevirinin doğrudanlığı” kapsamında ise Sevin tarafından yapılan ve Sevin'in ön söz yazdığı çeviri eserlerin hepsinin, kendisinin de belirttiği üzere, kaynak dilden doğrudan çeviriler olduğu anlaşılmaktadır. Nurettin Sevin'in, doğrudan kaynak dilden çeviriyi tercih ettiği ve ön sözlerinin tanıklığında, "metnin asıl kaynak dilden başka, aynı metnin farklı dillerden de çevrilmesine karşı tanınan hoşgörü eşiğini içeren" (Toury (çev. Eker), 2008, s. 15) "çevirinin doğrudanlığı" kapsamında ara dilden yapılan çevirilere olumlu bakmadığı iddia edilebilir. Çevirmenin ön sözlerinde belirttiği üzere, Oscar Wilde, William Shakespeare gibi "üstad" yazarları ara dilden çevirmenin büyük kayıplara sebep olabileceğini düşündüğü sonucuna ulaşılabilir (Bk. Bahtiyar Prens ve Başka Masallar, Julius Caesar).

Çevirmen, kendi sesiyle ön sözleri tanıklığında, bir aracı olarak iyi ve doğru okunduğunda çeviribilim araştırmacısına verimli sonuçlar sağlayan bir "bilgi kaynağı"dır (Krş. Akbulut, 2011). Çalışmada ele alınan çevirmen ön sözü örneklerinden varılan sonuçların bu döneme ilişkin yapılmış benzer çalışmalarla (Krş. Berk, 2004; Karadağ, Bozkurt \& Alimen, 2015; Karadağ ve Bozkurt, 2014; Tahir-Gürçağlar, 2018) büyük çoğunlukla örtüştüğü savunulabilir. Ön sözleri tanıklığında çevirmen Nurettin Sevin'in serüveninin, döneminin ve çevirmeninin çeviri ve kültür manzarasına kısmi olarak da olsa ışık tutabileceği ve çeviribilim araştırmalarına yeni kapılar açabileceği öngörülmektedir.

\section{Kaynakça}

Akbulut, A. N. (2011). Tanıklıklarla çeviri ve Cortázar. İstanbul Üniversitesi Çeviribilim Dergisi. 2(3), Alındığı URL = https://dergipark.org.tr/tr/pub/iuceviri/issue/1231/14422 (Erişim Tarihi: 13.05.2020).

Aksoy, N. B. (2016). Oscar Wilde in Turkish. B. Erol (Ed.), One Day, Oscar Wilde: Irish Writers Series 4 (ss. 27-35). Ankara: Bizim Büro. Alındığı URL = http://www.ide.hacettepe.edu.tr/ekitap3/1.pdf (Erişim Tarihi: 13.05.2020).

Aksoy, N. B. (2000). Kültür odaklı çeviri ve çevirmen. Türk Dili, 583, 51-57.

Artam, N. \& Sevin, N. (1948). Müslüman çocuğun kitabı, İstanbul: Milli Eğitim Basımevi.

Aşır, A. (2019). Sevin, Nurettin. Türk Edebiyatı Isimler Sözlüğü içinde. Alındığı URL = http://teis.yesevi.edu.tr/madde-detay/sevin-nurettin (Erişim Tarihi: 13.05.2020).

Aytaç, G. (1999). Türkiye'de edebi çeviri etkinliği. Ö. Yağcı (Ed.), Cumhuriyet dönemi edebiyat çevirileri seçkisi (ss. 347-349). Ankara: Kültür Bakanlığı.

Bengi-Öner, I. (2008). Çeviribilimde bireysel kuramlardan geniş ölçekli bir bakış açısına doğru. M. Rifat (Haz.), Çeviri Seçkisi I: Çeviriyi Düşünenler (ss. 159-174). İstanbul: Sel Yayıncılık. 
Berk, Ö. (2004). Translation and westernisation in Turkey: From the 1840s to the 1980s. İstanbul: Ege.

Birinci Türk Neşriyat Kongresi. (1939). Raporlar, teklifler, müzakere zabıtları. Ankara: TC Maarif Vekilliği.

Craig, G. (1946). Tiyatro Sanatı Hakkında (N. Sevin, Çev.). Ankara: Milli Eğitim Basımevi.

(Çığıraçan) Tüccarzâde İbrahim Hilmi (1997). Avrupalılaşmak: felaketlerimizin esbabı. Kitaphane-i Intibah (Haz. Osman Kafadar, Faruk Öztürk). Ankara: Gündoğan Yayınları.

(Çığıraçan) Tüccarzâde İbrahim Hilmi (1327/1911). Tasfiye-i Llisana muhtaç mıyız?-Türkçenin sadeleştirilmesi-. İstanbul: Matbaa-i Hayriye.

Dimitriu, R. (2009). Translators' prefaces as documentary sources for translation studies. Perspectives-studies in Translatology. 17(3), 193-206.

Edebiyatçılar Derneği'nden bir tıpkıbasım. 1. Neşriyat Kongresi. 06.05.1939 tarihli Cumhuriyet Gazetesi. Alındığı URL = http://earsiv.sehir.edu.tr:8080/xmlui/bitstream/handle/11498/8212/001582566010.pdf ?sequence=1 (Erişim Tarihi: 10.01.2020).

Er, S. (2009). Temel konuşma teknikleri - diksiyon. İstanbul: Hayat Yayıncılık, Tanıtım Bülteni.

Erem, T. \& Sevin, N. (1947). Milletlerarası fonetik işaretlerle konuşma dilimiz. İstanbul: Milli Eğitim Basımevi.

Erhat, A. (2008). Tercüme Bürosu ve Tercüme dergisi üstüne. M. Rifat (Haz.), Çeviri Seçkisi l: Çeviriyi Düşünenler (ss. 44-47). İstanbul: Sel Yayıncılık.

Erhat, A. (1942). Heredot Tarihi. Tercüme 2(12), 523-526.

Erşahin, i. (2004). Tüccarzade Ibrahim Hilmi Çığıraçan hayatı ve eğitim görüşleri. (Yayımlanmamış yüksek lisans tezi). Ankara Üniversitesi Sosyal Bilimler Enstitüsü, Ankara.

Genette, G. (1997). Paratexts, thresholds of interpretation (J. E. Lewin, Çev.). Cambridge: Cambridge University Press.

Holmes, J. S. (2008). Çeviribilimin adı ve doğası (A. Koş, Çev.). M. Rifat (Haz.), Çeviri Seçkisi II: Çeviri(bilim) Nedir? (ss. 107-120). İstanbul: Sel Yayıncılık.

Karagöz kursu ve Tunus'a giden Karagöz ekibi. (2018). Alındığı URL = https://www.karagoz.net/karagoz-kursu-ve-tunusa-giden-karagoz-ekibi.htm (Erişim Tarihi: 13.05.2020).

Kanıdinç, B. (2018). A case study on the translation of children's literature: Oscar Wilde's the happy prince and other tales. (Yayımlanmamış yüksek lisans tezi). Gazi Üniversitesi Sosyal Bilimler Enstitüsü, Ankara.

Karadağ, A. B., Bozkurt, E., \& Alimen, N. (2015). Çeviri ve yönlendirme: Sabiha ve Zekeriya Sertel'in çeviri çocuk edebiyatı eserleri. RumeliDE Dil ve Edebiyat Araştırmaları Dergisi, (2), 93-112.

Karadağ, A. B., \& Bozkurt, E. (2014). II. Meşrutiyet'ten Harf Devrimi'ne kadar Osmanlıcaya yapılan roman çevirilerinin süreç öncesi normlar bağlamında irdelenmesi. Humanitas-Uluslararası Sosyal Bilimler Dergisi, 2(3), 85-103. 
Karadağ, A. (2012). Çeviri tarihimizde fennî romanlarla bir kültür repertuarı oluşturmak. ï̈ Çeviribilim Dergisi, 3(6), 45-73.

Karantay, S. (2008). Tercüme Bürosu: Normlar ve işlevler. M. Rifat (Haz.), Çeviri Seçkisi I: Çeviriyi Düşünenler (ss. 48-54). İstanbul: Sel Yayıncılık.

Kayaoğlu, T. (1998). Türkiye'de tercüme müesseseleri. İstanbul: Kitabevi Yayınları.

Kovala, U. (1996). Translations, paratextual mediation, and ideological closure. Target. International Journal of Translation Studies, 8(1), 119-147.

Kuleli, M. (2016). Çeviri göstergebilimi bakış açısıyla Shakespeare'in Julius Caesar ve Antony and Cleopatra adlı oyunlarında anlam evreni, göstergeler ve öznelik yetisi. (Yayımlanmamış doktora tezi). Yıldız Teknik Üniversitesi Sosyal Bilimler Enstitüsü, İstanbul.

Niranjana, T. (1992). Siting translation: History, post-structuralism, and the colonial context. Berkeley, Los Angeles ve Oxford: University of California Press.

Ocak, B. (2008). Türkçenin sadeleştirilmesi tartışmaları etrafında ibrahim Hilmi Çığıraçan'ın görüşleri ve 'Tasfiye-i Lisana Muhtaç Mıyız?' adlı eserinin çeviriyazısı. Çağdaş Türkiye Tarihi Araştırmaları Dergisi, 7(16), 89-101.

Ocak, B. (2003). Tüccarzâde ibrahim Hilmi Çığıraçan: Bir yayıncının portresi. İstanbul: Müteferrika Yayınları.

Pym, A. (2014). Method in translation history. Londra ve New York: Routledge.

Sancaktaroğlu Bozkurt, S. (2014). Re-translations of Shakespeare's drama: A case study on the retranslations of A Midsummer Night's Dream. Ed. A. D. Bozer, Shakespeare 450 (95-107). Ankara: Hacettepe Üniversitesi, İngiliz Dili ve Edebiyatı Bölümü. Alındığı URL = http://www.ide.hacettepe.edu.tr/ekitap/SancaktarogluBozkurt.pdf (Erişim Tarihi: 13.05.2020).

Saral, S. (Söyleşiyi Yapan). (1999, 1 Nisan). "Ayla Algan ve Haşmet Zeybek Ille Söyleşi”. [Yüz Yüze Görüşme]. Alındığı URL = http://www.art-izan.org/artizan-arsivi/ayla-algan-ve-hasmetzeybek-ile-soylesi/ (Erişim Tarihi: 10.12.2019).

Semin, N. (1920). Mir'at-ı Şikeste. İstanbul: Matbaa-i Askeriye.

Sevin, N. (1973). On üç asırlık Türk kıyafet tarihine bakış. İstanbul: Milli Eğitim Basımevi.

Sevin, N. (1968). Türk gölge oyunu. İstanbul: Milli Eğitim Basımevi.

Shakespeare, W. (1958). Julius Caesar (N. Sevin, Çev.). Ankara: Maarif Matbaası.

Shakespeare, W. (1946). Hırçın kız (N. Sevin, Çev.). İstanbul: Milli Eğitim Basımevi.

Shakespeare, W. (1944). Bir yaz dönümü gecesi rüyası (N. Sevin, Çev.). Ankara: Maarif Matbaası.

Shakespeare, W. (1943). Venedik taciri (N. Sevin, Çev.). Ankara: Maarif Matbaası.

Shakespeare, W. (1942). Julius Caesar (N. Sevin, Çev.). Ankara: Maarif Matbaası.

Shakespeare, W. (1936). Yaz ortasında bir gecelik bir rüya (N. Sevin, Çev.). İstanbul: Hilmi Kitabevi.

Shaw, B. (1945). Caesar'la Kleopatra (N. Sevin, Çev.). Ankara: Milli Eğitim Basımevi. 
Sinanoğlu, S. (1941). Protogoras'ın tercümesi hakkında. Tercüme 1(5): 485-487.

Spivak, G. C. (2012). Outside in the teaching machine. Londra ve New York: Routledge.

Tahir-Gürçağlar, Ş. (2018). Türkiye'de çevirinin politikası ve poetikası: 1923-1960 (T. Demirel, Çev.). İstanbul: İş Kültür Yayınları.

Tahir-Gürçağlar, Ş. (2015). Kapılar: Çeviri tarihine yaklaşımlar (2.baskı). İstanbul: Scala Yayıncılık.

Tahir-Gürçağlar, Ş. (2008). Tercüme Bürosu nasıl doğdu. Birinci Türk Neşriyat Kongresi ve Çeviri Planlaması. M. Rifat (Haz.), Çeviri Seçkisi I: Çeviriyi Düşünenler (ss. 37-43). İstanbul: Sel Yayıncılık.

Tahir-Gürçağlar, Ş. (2002). What texts don't tell: The uses of paratexts in translation research. T. Hermans (Ed.), Crosscultural Transgressions (ss. 44-60). Manchester: St. Jerome Publishing.

Toury, G. (2008). Çeviri normlarının doğası ve çevirideki rolü (A. Eker, Çev.). M. Rifat (Haz.), Çeviri Seçkisi II-Çeviri(bilim) Nedir? (ss. 149-164). İstanbul: Sel Yayıncılık.

Toury, G. (2002). Translation as a means of planning and the planning of translation: A Theoretical Framework and an Exemplary Case. S. Paker (Ed.), Translations: (Re)Shaping of Literature and Culture (ss. 148-165). Boğaziçi Üniversitesi Yayınları: İstanbul.

Toury, G. (2000). The nature and role of norms in translation. L. Venuti (Ed.), The Translation Studies Reader (ss. 198-212). Londra ve New York: Routledge.

Türk Kadınları Kültür Derneği Faaliyetleri Konferanslar. Alındığı URL = http://turkkad.org.tr/201305-15-16-37-56/konferanslar.html (Erişim Tarihi: 03.01.2020).

Ülken, H. (1942). Eflatun tercümeleri. Ayın Bibliyografyası. 11-12, 16-17.

Üstün Külünk, S. (2018). Bir kültürel değişim öznesi olarak Tüccarzade İbrahim Hilmi Çığıraçan ve 1896-1963 yılları arasındaki yayıncılık faaliyetlerinde tercüme üzerine söylemi. Çeviribilim ve Uygulamaları Dergisi, (25), 181-198.

Venuti, L. (1998). The scandals of translation: Towards an ethics of difference. Londra ve New York: Routledge.

Waring, W. (1995). Is this your book? Wrapping postcolonial fiction for the global market. Canadian Review of Comparative Literature/Revue canadienne de littérature comparée, 22(3), 455-465.

Wilde, O. (1948). Ehemmiyetsiz bir kadın (N. Sevin, Çev.). İstanbul: Milli Eğitim Basımevi.

Wilde, O. (1939). Narlı ev (N. Sevin, Çev.). İstanbul: Hilmi Kitabevi.

Wilde, O. (1938). Bahtiyar Prens ve başka masallar (N. Sevin, Çev.). İstanbul: Hilmi Kitabevi.

Wilde, O. (1935). Salomé (N. Sevin, Çev.). İstanbul: Hilmi Kitabevi.

Yücel, H. A. (2011). lyi vatandaş, iyi insan. İstanbul: Türkiye İş Bankası Kültür Yayınları. 


\section{Ekler}

Ek-1: 06.05.1939 Tarihli Cumhuriyet Gazetesi

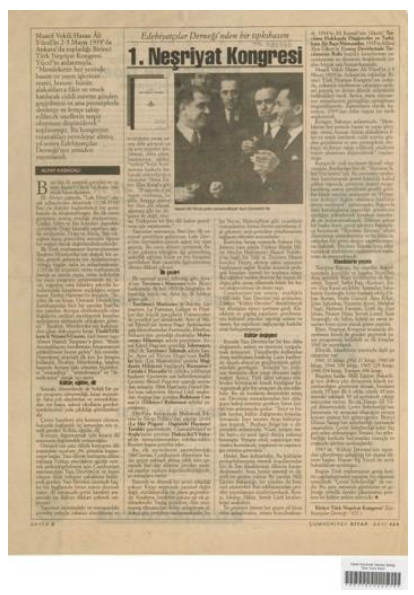

Ek-2: Bahtiyar Prens ve Başka Masallar (Wilde, 1938)

\begin{tabular}{|c|c|c|c|}
\hline -2a: & Ek-2b: & Ek-2c: & Ek-2d: \\
\hline 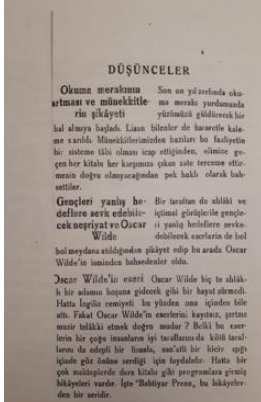 & 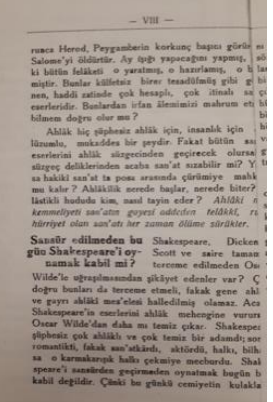 & 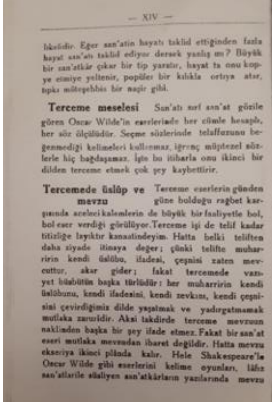 & 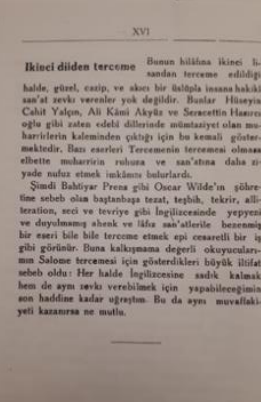 \\
\hline
\end{tabular}


Ek-3: Narlı Ev (Wilde, 1939)

Ek-3a:

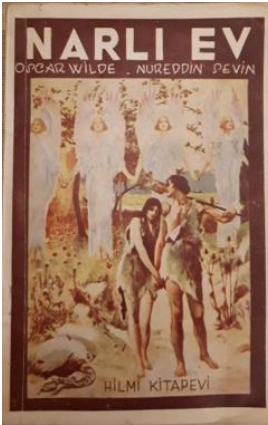

Ek-3b:

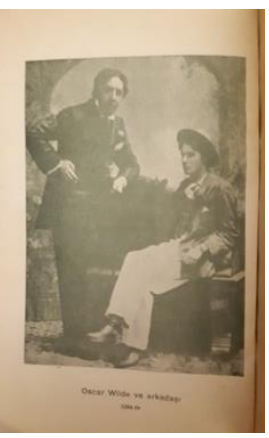

Ek-3c:

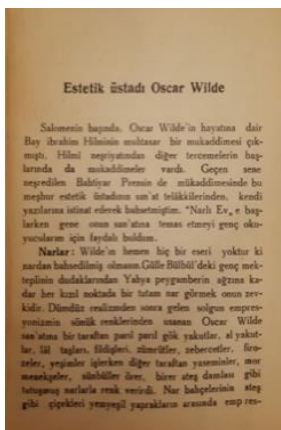

Ek-3d:

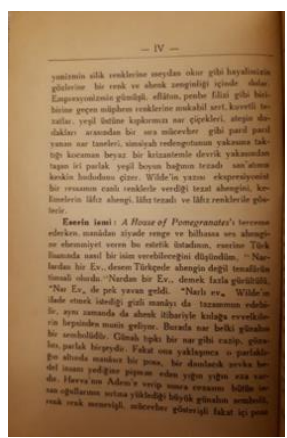

Ek-4: Venedik Taciri (Shakespeare, 1943)

Ek-4a:

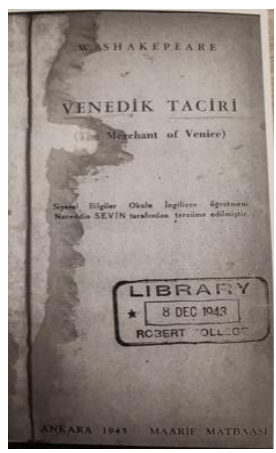

Ek-4b:

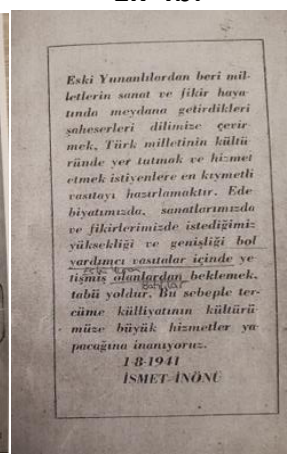

Ek-4c:

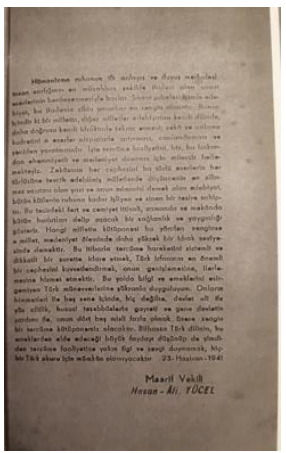

Ek-4d:

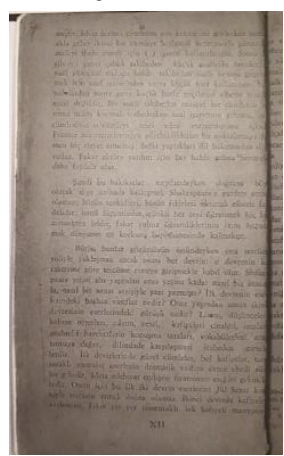

Ek-5: Ehemmiyetsiz Bir Kadın (Wilde, 1948)

\section{Ek-5a:}

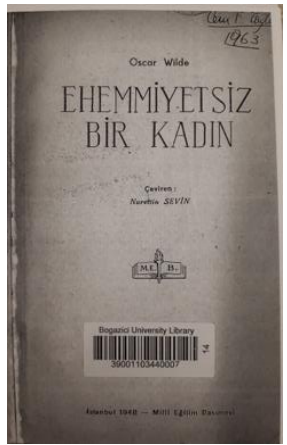

Ek-5b:

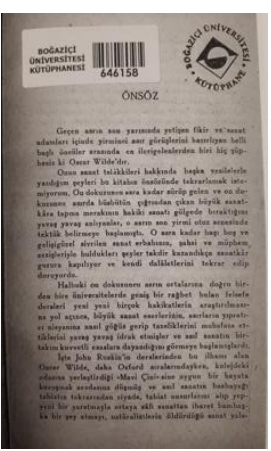

Ek-5c:

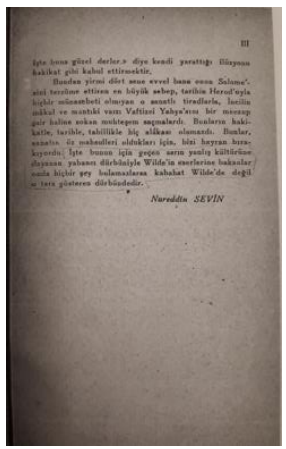


Ek-6: Julius Caesar (Shakespeare, 1958)

Ek-6a

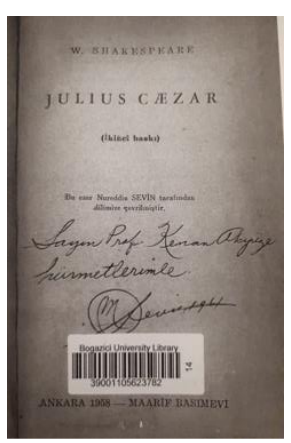

Ek-6b:

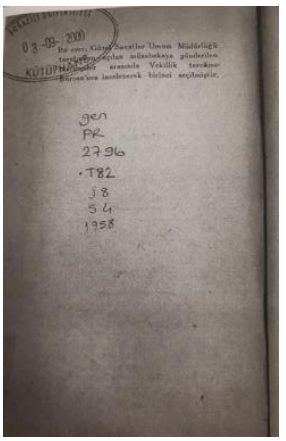

Ek-6c:

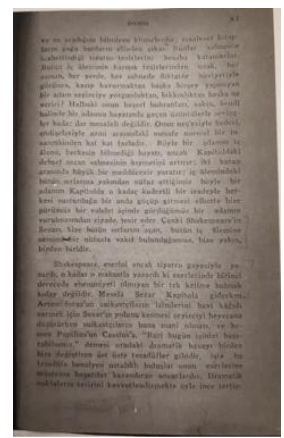

Ek-6d:

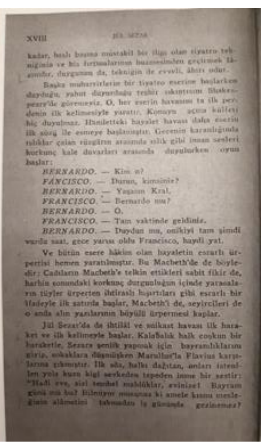

